\title{
Duties and Powers Respecting Foreign Crimes
}

Daniel H. Derby

Touro Law Center, dderby@tourolaw.edu

Follow this and additional works at: https://digitalcommons.tourolaw.edu/scholarlyworks

Part of the Conflict of Laws Commons, Constitutional Law Commons, and the International Law Commons

\section{Recommended Citation}

30 Am. J. Comp. L. Supp. 523 (1982)

This Article is brought to you for free and open access by the Faculty Scholarship at Digital Commons @ Touro Law Center. It has been accepted for inclusion in Scholarly Works by an authorized administrator of Digital Commons @ Touro Law Center. For more information, please contact Iross@tourolaw.edu. 


\title{
Duties and Powers Respecting Foreign Crimes
}

\author{
Daniel H. Derby*
}

There is considerable ambivalence in the attitude of the United States regarding the legal ramifications for the United States of offenses against the laws of other States. In general, the United States' position has been that under international law no State need concern itself with enforcement of the penal laws of another ${ }^{1}$ and that there is no clear duty to extradite an offender against the laws of another State who is found in the United States unless there exists a treaty providing the contrary. ${ }^{2}$ However, these generalities may be regarded as statements of historical attitude rather than present or future premises for conduct, for they have been eroded by exceptions and their validity as general propositions may be open to question because they are based respectively on a facile notion of the distinctiveness of penal laws of various States and on a casual blending of concerns for international law duties and constitutional law limitations of powers.

As a result, such important contemporary questions as when the United States recognizes a duty to extradite or to prosecute offenders against laws of other States cannot be answered succinctly without fear of reliance on rules with weak foundations. This brief writing attempts to illuminate such rules and their weaknesses in order to inquire into the valid principles available to address such questions.

It is useful to recall that matters involving States other than members of the federal union are regarded by the United States as falling within the exclusive competence of the federal government, and this exclusive competence extends to arrangements for extradition. ${ }^{3}$ This is a consequence of the United States Constitution, and interpretation of questions of federal constitutional law is left in the United States to the courts, the highest of which is the United

* Assistant Professor of Law, University of Akron. The assistance of Cheri Cunningham, J.D. cand. University of Akron is gratefully acknowledged.

1. Huntington v. Attrill, 146 U.S. 657 (1892) (applying the rule as between states of the union), citing The Antelope, 10 Wheat. (U.S.) 66, 123 (1825) for the proposition, "The Courts of no country execute the penal laws of another."

2. See note 30 infra and accompanying text.

3. Holmes v. Jennison et al., 14 Pet. (U.S.) 540 (1840), denied the power of a state of the union to deliver a fugitive to Canadian authorities during a time when the United States had no treaty of extradition with Great Britain and no federal statutes regarding extradition had been enacted. 
States Supreme Court. ${ }^{4}$ As a result, the legal principles available for consideration of legal questions in this realm are those generated by court decisions in accordance with common law principles of stare decisis, ${ }^{5}$ although it does appear that there are some peculiarities in constitutional law development like greater attention to articulated rationales of decisions and to academic writings. ${ }^{6}$

It may also be appropriate to recall that, as a federal system, the United States is composed of "states" among whom problems in extradition and effects of "foreign" penal laws arise. A sense of the contradictions within this area of the law may be obtained from considering that the duty of states to extradite within the federal system arises in part from the federal constitution, ${ }^{7}$ is regulated by both federal statute ${ }^{8}$ and an interstate compact, ${ }^{9}$ as well as state laws, and yet situations arise in which extradition is legally required yet not compellable. ${ }^{10}$ Because federal conceptions regarding crimes involving more than one jurisdiction are derived from similar principles, it is useful at times to refer to the interstate model, although it is apparent that even among the states of the union conceptual difficulties linger.

On the international plane it may be that extradition represents the major thrust of international cooperation, but this must be viewed-at least from the perspective of the United States-as a departure from the more general rule that one State need not concern itself with enforcement of the penal laws of another. ${ }^{11}$ Surprisingly, this general rule prevails among states of the union, so that one

4. This well-established but extraordinary practice finds no express basis in the United States Constitution but was adopted by the Supreme Court in the course of deciding a case. Marbury v. Madison, 1 Cranch (U.S.) 137 (1803). A helpful exposition from a comparative perspective is Giraudo, Comment-Judicial Review and Comparative Politics: An Explanation for the Extensiveness of American Judicial Review Offered From the Perspective of Comparative Government, 6 Hastings CoNST'L L.Q. 1137 (1979).

5. A classic of some utility to comparativists seeking to appreciate United States case law analytical techniques and problems is K. Llewellyn, THE Common LAw TrA. DITION (1960).

6. In addition to Llewellyn, note 5 supra, analysis of constitutional law problems may be aided by Choper, On the Warren Court and Judicial Review, 17 CATH. U.L. REv. 20 (1967).

7. U.S. Const. Art. IV, sec. 2.

8. 18 U.S.C. 3182.

9. Uniform Criminal Extradition Act, 9B Uniform LAws AnNotated (1957), enacted by all states of the union. See, e.g. N.J.S.A. 2A:160-10 and Ill. Rev. Stat. ch. 60, sec. 18 (1977).

10. The cornerstone case is Drew v. Thaw, 235 U.S. 432 (1914), holding that despite the clear duty of a governor to extradite under the Constitution and other laws, compulsion by court action is unavailable unless a state law so provides because no power to so compel is invested in the federal courts. For a thorough discussion including recent cases, see, "Comment-Interstate Extradition: Should the Asylum State Governor Have Unbridled Discretion?" 1980 B.Y.U.L. REv. 376.

11. The Antelope, note 1 supra. The generality of the rule is not based solely on its inherent qualities but also on the general United States approach to such matters. See Bassiouni, International Extradition: A Summary of the Contemporary American Practice and a Proposed Formula, 15 WAYNE L. REv. 733, 759 (1969). 
state will not ordinarily enforce the penal judgment of another ${ }^{12}$ despite relative similarity of penal laws, punishments and social policies, and despite both theoretical ${ }^{13}$ and real mobility of populations in moving between states. In view of this, the national position that the United States does not recognize or enforce foreign penal judgments ${ }^{14}$ is natural.

However, just as the states of the union now, in a practical sense, help to enforce federal penal judgments by allowing federal convicts to be kept in state penal institutions, ${ }^{15}$ the federal government has now undertaken through treaties to enforce penal judgments of states that are truly foreign in the international sense, and has even given express recognition to such judgments in the most recent of such treaties. ${ }^{16}$

Moreover, although neither the federal nor the various state governments have accorded recognition per se to penal judgments other than their own, they have nevertheless found it appropriate to accord legal significance to such judgments in various ways, ${ }^{17}$ so that the significance of the term "recognition" must be questioned before the general rule's operation can be appreciated. Although the occasion for an exception to that general rule is often provided

12. Huntington, note 1 supra. Generally the states of the union have taken the rule stated in that case literally and have felt that they not only need not but rather ought not grant such enforcement. There have, however, been exceptions, such as in the handling of judgements for nonpayment of taxes. Still, the practice stands in stark contrast to the Constitutional mandate that sister states give "full faith and credit" to one another's laws (U.S. Const. Act. IV, sec. 1), which has been held to require enforcement of a wide range of civil judgments.

13. The United States Constitution guarantees a right to travel between states U.S. Const. Art. IV, sec. 2.

14. For a discussion of the outward rigidity of the United States position, see, Bassiouni, "Treaties on the Execution of Penal Sentences between the United States and Mexico, and the United States and Canada," 1 Comp. L. Ybk. 1, 11-15 (1977).

15. Federal arrangements are accomplished by regarding the state institution as if it were loaned to the federal government; arrangements between states are governed by the Interstate Corrections Compact, e.g. Ill. Rev. Stat. ch. 38, secs. 1003-4-4 (1977).

16. See, Note--The Prisoner Transfer Treaty with Turkey: Last Run for the Midnight Express, 84 Dickinson L. REv. 687 (1980). On this and other prisoner transfer treaties, see Bassiouni, note 14 supra; and Kowalski, Penal Transfer Treaties and the Application of Unconstitutional Conditions Analysis, 12 U. TOLEDO L. REV. 1 (1980) (discussing United States treaties with Mexico, Canada and Bolivia).

17. One obvious way is through immigration laws excluding aliens who have been involved in prostitution or convicted of crimes involving moral turpitude. 8 U.S.C. 125l (a) (12) and (a) (4), respectively. For early operation of comparable laws and an indication of their functional relation to extradition, see J.B. Moore, EXTRADITTON, v.I, 38-39 (1891).

A more stunning use of a foreign conviction was Cooley.v. Weinberger, 518 F.2d 1151 (10th Cir. 1975), in which a woman was denied her deceased husband's social security benefits on the basis of an Iranian conviction for his murder.

They are also used for multiple offender status. See Burgett v. Texas, 389 U.S. 109 (1967); U.S. ex rel Savini v. Jackson, 234 F.2d 742 (2d Cir. 1957); and U.S. ex rel Foreman v. Fay, 184 F.Supp. 535 (S.D.N.Y. 1960). For an analysis of the problems involved, see note 18 infra and Pye, The Effect of Foreign Criminal Judgments in the United States, 32 U.M.K.C.L. REv. 114 (1964). 
by a statute, such statutes commonly create conceptual difficulties that make the scope and nature of such exceptions problems for judicial determination. ${ }^{18}$

It seems a fair comment on United States law in this area to state that principles for dealing with such conceptual difficulties are poorly developed. ${ }^{19}$ Such lack of development may be attributed in part to the availability of extradition as a vehicle for obviating important, difficult problems. Among states of the union, criminal law cooperation may be an important consideration, but it is easily addressed by extradition; on the international level criminal law cooperation may have been regarded as important only where the foreign State was one with which the United States has had well-developed relations-in which case a treaty of extradition would ordinarily exist ${ }^{20}$-and in other circumstances solutions of a more simplistic nature may have been acceptable. ${ }^{21}$

Extradition, however, is no panacea to such problems, for it cannot at all solve some problems and it may itself generate additional problems. A prime example in the former category is corporate criminality; in the latter, the political offense is a classic example and crimes of truly international concern present a novel example.

Thus, when "foreign" corporations in either an interstate or international sense cause criminal effects within the relevant jurisdiction, extradition is unavailing and, as a result, the relevant state may elect to treat the conduct producing such effects as a violation of its own laws despite its geographically remote situs. This has led

18. People v. Olah, 300 N.Y. 96, 89 N.E.2d 329 (1949), is an outstanding example. there the court attempted to determine what significance to attach to an offender's prior conviction in New Jersey for a similar offense where the two states used different values of goods to divide between felony and non-felony property crimes and the offender had engaged in conduct in New Jersey that would have been a felony had it been done in New York. For more on analytical problems of this sort, see Pye, note 17 supra.

19. One of the more bizarre examples of conceptual problems is dealt with in State v. Luv Pharmacy, 118 N.H. 398 (1978), in which it was determined that New Hampshire had jurisdiction to criminally prosecute Penthouse Magazine for causing a criminal effect in that state-the sale of obscene material-but the court found it necessary to consider whether the magazine's conduct was legal where it occurredNew York-and concluded it was not, despite the lack of a New York prosecution and varying interpretations of obscenity in the two states. (Penthouse was not regarded as having been "present" in New Hampshire, and jurisdiction was based on "long arm" service of process, as is done with civil suits-and this part of the court's analysis seems quite sound.)

20. The tendency of the United States to have such treaties with most nations of the "civilized world" was noted in U.S. v. Rauscher, 119 U.S. 407 (1886). As of 1981, 98 bilateral treaties of extradition were listed in 18 U.S.C.A. 3181.

21. It is sometimes opined that such cooperation is a function of comity, and it is natural to assume that comity bears an inverse relationship to the tendency of States to see crimes as falling within the political offense category, which has traditionally made non-extradition excusable. The matter is give thoughtful treatment in a recent volume that is the only English-language treatise on the subject, C. Van den Wijngaert, The Polttical Offence Exception to Extradition: The Delicate Problem of Balancing the Rights of the Individual and INTERnational PUblic Order (1980). 
to serious conceptual difficulties on the interstate ${ }^{22}$ and international $^{23}$ levels because traditional notions of jurisdiction are inadequate to explain how one state can punish conduct occurring in another that the other has countenanced. ${ }^{24}$

Indeed, the entire concept of extradition, from a United States perspective, is colored by the notion that no meaningful trial can occur in the absence of the accused, ${ }^{25}$ so that "presence" of the accused occupies a special place of concern, and this does not adapt well to corporations, which under the United States view can be "present" in many places at once, ${ }^{26}$ and it does not offer promise for resolution of questions of which state is to have custody of an accused when the accused has violated the laws of more than one state. ${ }^{27}$

Nevertheless, under the United States view, extradition is treated as a legal subject unto itself, ${ }^{28}$ and although it obviously represents an exception to the more general rule that States need not concern themselves with enforcement of the penal laws of other States, no attempt to explain extradition in this relation has been made by United States courts. ${ }^{29}$

The United States view, as expressed in decisions of its Supreme Court, has been that in the absence of a treaty no duty to

22. See note 19 supra.

23. See, e.g. Note, Taming the Transnationals: An Examination of Structural Solutions to Regulation of Transnational Enterprise and the Theoretic Problem of Sovereignty, 7 W.ST. U.L. REv. 187 (1980).

24. Sorne of the most dramatic problems have involved United States enforcement of its antitrust laws against corporations whose violative conduct occurred abroad, causing effects in the United States market. Recent efforts to produce a more reliable analytical framework are Mannington Mills, Inc. v. Congoleum Corp., 595 F.2d 1287 (3rd Cir. 1979), and Timberland Lumber Co. v. Bank of America, 549 F.2d 597 (9th Cir. 1976). A classic case is United States v. Imperial Chemical Industries Ltd., $100 \mathrm{~F}$. Supp. 504 ((S.D.N.Y. 1951), final decree issued 105 F. Supp. 215 (1952). Contemporary guidelines for enforcement reflect concern for the paradox involved. Antitrust Guide for International Operations Antitrust Division, U.S. Dept. of Justice (1977), reprinted in ANTITRUST AND TRADE REg. RPT, 799.

25. The keystone federal case for the proposition that presence of the accused is necessary to preserve constitutional rights in Lewis v. United States, 146 U.S. 370 (1904). A startling requirement that corporations must be present at their trials was stated in People v. Consolidated Edison Co., 42 Misc.2d 422 (N.Y. 1964).

26. Domestically, International Shoe Co. v. Washington, 326 U.S. 310 (1945), is a classic illustration. The United States view of the international law principles is stated in Restatement Second of the Foreign Relations LAW of the UNited STATES, ch. 2 (1965).

27. Uniform Criminal Extradition Act, sec. 5, note 9 supra, for example, provides for the possibility of extradition from one state of the union where an offender is serving a sentence to another state for trial, with return of the offender to complete the first seritence, subject to possible reextradition to serve any sentence that was imposed in the second state.

28. In re Scheazle, Fed. Cas. No. 12,734 (c.c. Mass. 1845), describes it as but one step in the arrest and delivery for trial of an accused.

29. In considering whether, in the absence of a treaty, there exists an international duty to extradite, the United States courts have not resorted to the rule recited in The Antelope, note 1 supra, but have instead considered the writings of publicists and State practices regarding extradition itself. See cases cited in note 30 , infra. 
extradite clear enough to recognize and act upon exists under international law. ${ }^{30}$ However, the authoritative quality of this position is open to question on several counts.

First, in no case before that Court, nor in any reported case before any other federal court, has there been an attempt to extradite a person where no treaty existed between the requesting State and the United States. Accordingly, the necessity of such a pronouncement is questionable, and it is clearly of less dignity than a holding of a case. ${ }^{31}$ Moreover, in the case in which that statement was most nearly necessary, there was in existence a treaty and the same result in the case could have been reached by ordinary United States treaty interpretation, ${ }^{32}$ so that it cannot be accepted without reservation as part of the essential rationale of any decision.

Second, the cases voicing this position have relied in part on the view that under the federal constitution's division of powers the executive branch is without authority to extradite a person unless a treaty so providing is in force. Yet the authoritativeness of this observation is undercut by three factors: besides the nonessential character of this proposition, even if it were true it would not in itself establish whether an international law duty existed; ${ }^{33}$ the cases

30. The rule is stated in United States v. Rauscher, note 20 supra at 411-12 as follows:

It is only in modern times that the nations of the earth have imposed upon themselves the obligation of delivery up these fugitives. . . This has been done generally by treaties. . . Prior to these treaties and apart from them. . .there was no well-defined obligation on one country to deliver up such fugitives. (Emphasis added).

Similar wording appears in Factor v. Laubenheimer, 290 U.S. 276. 287 (1933):

While . . . it has been said that (a State) is under a moral duty to (extradite) ... the legal right to demand his extradition and the correlative duty to surrender him to the demanding country exists only when created by treaty.

Valentine v. United States ex rel. Neidecker, 299 U.S. 5 (1936), relied on these authorities and text writers in making a similar pronouncement.

31. Although United States courts interpret the federal constitution, the obvious tension between this role and the principle of separation of powers is controlled in part by the requirement that such interpretations are not binding unless they were essential to resolution of a case properly before the court. See, e.g. Giraudo, note 4 supra, and Choper, note 6 supra.

32. Valentine, note 30 supra seems the closest to this issue, for Factor and Rauscher, note 30 supra, clearly involved treaty interpretation, the former as to the meaning of a treaty term requiring that offenses involved be criminal in both States; the latter whether a prosecution for an offense not named in the demand for extradition was proper. In Valentine the relators were United States citizens whose extradition was sought under a treaty that expressly provided that "neither of the contracting parties shall be bound to deliver up its own citizens or subjects. . ." Treaty of Extradition with France, Jan. 6, 1909, act. V, 37 Stat 1526 (1913), T.S. No. 561. Obviously one interpretation of the problem actually before the court would be that whether any duty of a general sort had existed prior to the treaty, France had waived any right to demand extradition of United States citizens. Moreover, extradition of nationals as opposed to aliens presents a very different question under international law because the custom of most States has been to refuse to surrender nationals. See, e.g. M.C. Bassiouni, INTERnational EXTradition AND WORLd PUblic Order 13436 (1972).

33. For example, in Valentine, note 30 supra, the language of the treaty actually 
that have raised kindred issues arose after Congress enacted legislation that has been interpreted as requiring that there be a treaty, so that the question of what powers the executive might have had, had Congress not imposed such a requirement, was not properly before the courts; ${ }^{34}$ and this observation was based in part on views expressed by the executive branch, which views are of questionable authoritativeness, particularly since contrary views have, at times, been not only expressed but acted on as well. ${ }^{35}$

Third, even if the language of the Supreme Court were regarded as an authoritative expression of United States law, its wording is not unequivocal, for it does not deny altogether the existence of a duty to extradite in the absence of a treaty but merely asserts that any such duty is not clear enough to be acted on, suggesting that the role of a treaty would be one of clarification rather than creation of an obligation. Accordingly, it is possible that a duty to enter into a

in force could have been viewed as a limitation on executive powers that might have existed absent the treaty, and in fact the court there utilized the principle of interpretation expressio unius to find that extradition of nationals was negated by the treaty. The dual inquiry of whether an international duty to extradite exists and whether the United States executive has power to deliver certain persons may be justifiable under the exigencies of decision-making in a context like Valentine's, but they are clearly separable issues, for the United States openly admits that constitutional inability to perform international duties does not excuse such nonperformance. See Restatement of the LaW-Foreign Relations Law of the United States (Revised) Tentative Draft No. 1 (1980). sec. 135(3). Accordingly, blending the two issues is unfortunate.

34. In Re Metzger, 5 How. (U.S.) 196 (1847), it was held that in the absence of legislation the manner of accomplishing extradition was up to the executive. At that time an applicable treaty was in effect, but no statute regulating the process was enacted until 1848. Act of Aug. 12, 1848, 9 Stat. 303. That statute and the one currently in effect, 18 U.S.C. 3181 (1980), contain recitation that they will apply when a treaty extradition is in force. All of the decided cases have arisen under treaties, so that there is no unequivocal authority as to executive powers in the absence of a treaty and only Metzger suggests what powers exist absent Congressional action.

35. Moore, note 17 supra, has been relied on by the courts for the conclusion that the executive branch takes the view that it is constitutionally unable to extradite in the absence of a treaty. Moore builds significant evidence to this effect and does state such a conclusion, but also discusses instances where the executive branch has taken contrary positions. For example, in 1797 an attorney general expressed officially the view that the United States had a duty to extradite to Spain despite the lack of a treaty. 1 Op. A-G. 689, cited in Moore at 19. In 1796 the Secretary of State informed Great Britain that extraditions for offenses not mentioned in the treaty between the two States providing for extradition will be "at the discretion of the two governments; but that this discretion will advise the delivery in cases affecting the great interests of society." MSS. Dept. of State, cited in Moore at 30. Moore at 33-35 discusses an 1864 delivery of a fugitive in the absence of a treaty, done by Secretary of State Seward so speedily that no legal challenge was possible. President Lincoln delivered to an agitated Senate a report by Seward explaining his action, which stated in part: "(A)lthough it may be conceded that there is no national obligation to make such a surrender on a demand therefor ... a nation is never bound to furnish asylum and . . .if, in any case the comity could with propriety be practised, (this case) furnished a just occasion for its exercise." Dip. Cor., 1864, part 2, p. 60. The offender had stolen and then sold eleven hundred slaves. In three instances the United States has requested fugitives and committed itself to reciprocity at a time when no treaty of extradition was in force, in 1797, 1855 and 1878. Moore at 42-43. 
treaty may have implicit recognition in United States law, at least once an offender's extradition has been requested, and, despite the United States' aversion to ex post facto laws, extradition under a treaty not in force at the time the offense was committed has been expressly approved by the courts. ${ }^{36}$

The authoritativeness of the proposition that the executive is without authority to extradite in the absence of a treaty is further eroded by court approval of the functional equivalent of extradition where there existed only an executive agreement achieved pursuant to a very vague grant of legislative authority. ${ }^{37}$ Given that legislative acquiescence can so easily be found, it may be that contemporary executive agreements, which are required to be reported to Congress for potential overriding, ${ }^{38}$ may be regarded as acceptable vehicles for extradition if they are so reported and no negative legislative action follows. ${ }^{39}$

As a result, although the position of the executive branch has fairly consistently been that it is unable to extradite individuals except under a treaty, and the courts have echoed this view and added that there is no clear international duty in the absence of a treaty, United States law is not inconsistent with the view that, when an offender found in the United States is demanded for extradition by a State in which he has committed a crime, the United States not only can but is obligated to enter into an arrangement for his extradition. However, affirmative support for such a proposition is lacking. ${ }^{40}$

36. Re De Giacomo, 12 Blatchf. 391 (C.C. N.Y. 1874) Fed. Cas. No. 3747. There, however, the court attached importance to the fact that the conduct involved was criminal in both States at the time it occurred, so that only the treaty was after-thefact. Because extradition is procedural in character, having been described as but one step in the arrest and detention of an accused, see note 28 supra, the outcome is not startling, despite U.S. Const. Act I, secs. 8(3) and 10(1).

37. In Williams v. Rodgers, 449 F.2d 513, cert. den. 405 U.S. 926 (1971), the transfer of a serviceman back to the Philippines for trial by a Philippine court for a common crime was approved on the basis of a Status of Forces Agreement (SOFA) providing that Phillipine courts would have United States cooperation in trying such offenses. The SOFA was an executive agreement made pursuant to a post-World War II Congressional resolution calling for the President to make appropriate arrangements to maintain military bases in the Phillipines. Somewhat similar is Wilson v. Girard, 354 U.S. 524 (1957), where authority was found in a treaty. Because such cases seem to hinge on a manifestation of legislative acquiscence, they also raise doubts about the constitutional dimension of the issue. For a general discussion, see Norton, "U.S. Obligations Under Status of Forces Agreements: A New Method of Extradition," $5 \mathrm{Ga}$. J. Int'l \& Comp. L. 5 (1971).

38. The Case Act, Pub. L. 92-403, Sec. 1; Aug. 22, 1973; 86 Stat. 619.

39. See, e.g. Rovine, Separation of Powers and International Executive Agreements, in Symposium on Separation of Powers, 52 IND. L. J. 311 (1977). Also discussing this problem as well as a more recent similar one is Berger, The PRESIDENT's Unilateral Termination of the Taiwan Treaty, 75 Northwestern U. L. Rev. 577 (1980).

40. But see note 35 supra. Also, it is useful to note the depth and persistence of the notion that an international duty to extradite exists, which is explored from its Roman law origins as civitas maxima in Bassiouni, INTERNATIONAL EXTRADITION AND World Public Order: A Conceptual Evaluation, in Aktuelle Probleme den InTERnationalen StrafsRecht (Oehler and Plotz eds. 1970). 
Thus it may be that, although comity is not regarded by the United States as a basis for extradition, comity is a basis for an obligation to enter into a treaty that would itself be a basis for extradition. Yet even were this accepted, serious questions would arise or persist regarding the circumstances under which extradition would be required, for the United States recognizes several special requirements as customary.41 Whether such requirements would be viewed as limitations under international law on the duty to arrange for extradition ${ }^{42}$ or upon the power of the federal government to extradite ${ }^{43}$ would have to be considered.

There remains the question of whether these legal considerations might be different with respect to particular classes of crimes, such as those addressed by international conventions requiring signatories to provide for extradition or prosecution of those who commit such crimes. As to these crimes, it is interesting to note that those actually addressed by conventions to which the United States is a signatory would then come within a conventional duty to arrange for extradition rather than any duty the United States might recognize as arising from general international law. Likewise, the character of such crimes is likely to be such that no difficulties with special requirements would arise.44 However, as to crimes addressed by conventions to which the United States is not a signatory, it would seem that no special legal significance would attach unless the convention were so widely adhered to that it constituted convincing evidence of the emergence of a preemptive norm by operation of customary international law, and none of the existing conventions appears likely to so qualify. ${ }^{45}$

41. Among the requirements commonly inserted in United States extradition treaties are that the offense have occurred within the jurisdiction of the requesting State, that the conduct have been criminal in both States at the time of its occurrence, that the conduct did not constitute a political offense, and that persons extradited should be tried only on offenses for which extradition was sought and granted. See Bassiouni, note 11 supra.

42. Jurisdiction of the requesting State would seem to be a requirement, but double criminality would seem unnecessary so long as the conduct was criminal where it occurred, thereby satisfying the maxim nulla poene sine lege. On the other hand, if the duty of extradition relates to comity, the lack of criminal proscription in the asylum State could be viewed as negating any inference of comity as to this kind of conduct.

43. Here, double criminality seems to pose special problems, for a procedure in the nature of extradition would seem difficult to justify in the absence of a municipal law norm that has been violated by the person in question.

44. The names of the conventions indicate the character of the conduct involved. Examples are: The Single Convention on Narcotic Drugs, 18 U.S.T. 1407, T.I.A.S. 6298; The 1971 Convention on Psychotropic Substances, U.N. Doc. E/4606/Rev. 1, Annex IV (May 1969), with a 1972 Protocol, U.N. Doc. E/Cong. 6318 (1972); the Tokyo Convention on Offenses and Certain Other Acts Committed on Board Aircraft, 20 U.S.T. 2941, T.I.A.S. 6278 (1963); The Hague Convention for the Suppression of Unlawful Seizure of Aircraft, 22 U.S.T. 1641, T.I.A.S. 7192 (1970); and the Montreal Convention for the Suppression of Unlawful Acts Against the Safety of Civil Aviation, 24 U.S.T. 564 (1971).

45. The United States is a signatory to the conventions listed in note 44 supra. 
Whether a duty to prosecute offenders against foreign states is recognized by the United States as arising under international law involves very different considerations, ones relating to poorly defined concepts of criminal jurisdiction and relatively distinctive notions of prosecutorial duties.

The United States view of criminal jurisdiction begins with qualifications of the circumstances under which such jurisdiction may be asserted and takes the view that such jurisdiction may be asserted as to conduct within a State's territory or conduct affecting that State's properly protected interests. ${ }^{46}$ It is recognized that piracy affects the interests of all States so that any State may assert jurisdiction to try pirates, ${ }^{47}$ and it may be that similar recognition might be given to war crimes and possibly some crimes dealt with by conventions providing for extradition and prosecution obligations. ${ }^{48}$ However, for most foreign common crimes the United States would regard itself as unable, under international law, to assert jurisdiction, and under its own constitution it would also be unable to assert jurisdiction. ${ }^{49}$ For crimes over which the United States regards itself as unable, under international law, to assert jurisdiction, the United States would obviously recognize no duty to assert jurisdiction.

The problem lies with crimes over which the United States sees itself as able, under international law, to assert jurisdiction. There would seem to be no divergence between United States views of international law capacity and constitutional capacity in this regard, ${ }^{50}$ but when an offense has a foreign element there is an overlapping of jurisdictional claims that presents difficulties.

One situation calling for resolution of such a conflict of jurisdiction is where an offender is found in the United States and is requested for extradition by a State whose penal laws have been

The main conventions mentioning extradition duties to which the United States is not an adherent are the Convention on the Suppression and Punishment of the Crime of Genocide, G.A.O.R. Res. 260 at 174, U.N. Doc. A/181 (1948); and the International Convention for the Suppression and Punishment of the Crime of Apartheid, G.A. Res. 3086, 28 GAOR (No. 50), U.N. Doc. A/9233/ Add. 1 (30 Nov. 1973). The former enjoys wide adherence, but its provision as to extradition is mandatory only as to the duty not to treat genocide as a political offense. The latter is adhered to by a minority of States and also contains a weak extradition provision.

46. Restatement, note 26 supra, sec. 33; Moore, note 17 supra at 134-35.

47. Restatement, op. cit., sec. 34 ; Moore, op. cit. at 141-43.

48. RESTATEMENT, op. cit. secs. 35 and 36 provides for jurisdiction regarding certain maritime activities. Restatement of THE Foreign ReLATIONS LAw OF the UNITED STAtes (REvised), TENT. Dr. No. 2, sec. 404 (1981), provides for universal jurisdiction to define and punish such crimes as piracy, slave trade, genocide and war crimes. Also, see Moore, op. cit. at 143-44, discussing authority to the effect that the British view that jurisdiction may be exercised as to offenses against the Law of Nation's may be applicable.

49. Except for the special situations described in notes 47 and 48 supra, and others not here relevant, the United States adheres to a territorial view of jurisdiction. See, e.g. Bassiouni note 11 supra at 739-41.

50. Compare International Shoe, note 26 supra, with RESTATEMENT, note 48 supra, sec. 441 . 
violated by that offender. Traditionally, on the international plane, the United States has required in its extradition treaties that the offending conduct have occurred within the territory of the requesting State, ${ }^{51}$ but no extradition will occur if the requesting State is attempting to assert jurisdiction on the basis only of protected interests. Where the conduct has occurred within the territory of the requesting State, if it has offended the interests of a third State, that fact will be without consequence under United States practice, but if it has offended the interests of the United States there must be a determination whether to prosecute or extradite-or perhaps both. Likewise, if the conduct occurred within the United States, although extradition would not be granted to a requesting State merely because it:s interests were affected, there remains the question of whether the United States would prosecute such an offender.

Under the federal constitution the United States would regard itself as unable to prosecute in either of the situations just described unless there existed at the time of the conduct a penal law proscription meeting certain requirements. ${ }^{52}$ The existence of a treaty providing merely for extradition had the conduct occurred within the requesting State would not suffice for this purpose, ${ }^{53}$ nor would a convention providing for a duty to prosecute or extradite appear sufficient. ${ }^{54}$ Therefore, in the absence of proper legislation the United States would constitutionally be unable to prosecute.

The United States view of international law on this matter would be that its constitutional incapacity does not justify nonperformance of an international obligation, ${ }^{55}$ but there would be no international obligation except in the latter case, where, by international agreement, the United States undertook to either extradite or prosecute. The existence and scope of that obligation would involve treaty interpretation, and if it were the case that the United States was bound to either prosecute or extradite, the United States would be responsible for violation of a treaty obligation under the principles of State responsibility.

Likewise, were the prosecution possible because an appropriate proscription existed, yet the United States did not prosecute, its responsibility would be clear.

However, only in the latter situation would the State whose interests had been injured have any chance for a satisfactory remedy. Assuming the United States straightforwardly acknowledged its re-

51. Bassiouni, note 49 supra.

52. See note 43 supra.

53. Although such treaties are regarded as self-executing, Re Metzger, note 34 supra, decisional law suggests that the requirement of double-criminality is implicit in them. Wright v. Henkel, 190 U.S. 40 (1903).

54. For steps in enforcement of a foreign penal judgment through the indirect device of prisoner transfer treaties it was regarded as advisable to enact detailed legislation. 18 U.S.C. 4100-14 (1978). See Bassiouni, note 14 supra.

55. See Restatement, note 33 supra. 
sponsibility in the specific case ${ }^{56}$ the United States would be unable in the first instance to provide the relief actually desired by that State because it would also be unable to extradite, ${ }^{57}$ and no treaty provisions or international tribunal decisions could alter this. In the latter situation, however, it might be possible for the executive to compel prosecution and the executive might well opt to do so once responsibility was acknowledged. Also, extradition might be possible through a post hoc arrangement. However, there would seem to be no effective means for the foreign State to compel either of these results should the executive be uncooperative for there is no mechanism under United States law to compel prosecutions, commencement of extradition proceedings, or negotiation of international agreements, and even a decision of an international tribunal as to the wrongfulness of the executive's inaction would not make such compulsion possible. ${ }^{58}$

It would appear, therefore, that where the United States is constitutionally unable to fulfill its obligation or its executive refuses to do so, the only remedy for the aggrieved State would be unilateral action. Such action could take the form of denunciation of the treaty that created the obligation or withholding performance of a similar obligation to the United States under that or a similar treaty, but such actions would be of little consolation because the purposes to be achieved by performance of such obligations were implicitly recognized by the aggrieved State as desirable to it when it entered into such treaties.

A very interesting alternative, but one likely to be of limited availability, would be to have the victims of the offense in question proceed against the offender in United courts on the basis of tort law. ${ }^{59}$

56. Authoritatively establishing breach of duty by the United States would be impeded by the facts that the United States is not a signatory to the Optional Protocol to the Statute of the International Court of Justice, does not provide for arbitration in its extradition treaties (see, Draft Model Treaty of Extradition, 41 Fed. Reg. 51897, No. 228 (1976)), and is unlikely to agree to arbitration in such matters because such arbitration is not customary among States and might expose the United States to embarrassment due to inability to perform a duty, as discussed infra.

57. See notes 43 and 52 supra and accompanying text.

58. The ability of anyone to compel the executive to act or refrain from action in the conduct of foreign affairs is doubtful. See Goldwater v. Carter, 444 U.S. 996 (1979), discussed in Miller and Oliphant, Evenly Dividing a Nine-Member Court: The Political Question Doctrine in Coleman v. Miller, Goldwater v. Carter and Idaho v. Freeman, 1980 Det. Col. L. Rev. 789. In that case a Senatorial challenge to presidential power to terminate a treaty was rejected. See also Berger, note 39 supra and Drew, note 10 supra. As for prosecution itself, in the United States the prosecutor has discretion that is beyond the power of the courts to direct affirmatively.

59. Filartiga v. Pena-Isala, 630 F.2d 876 (2d Cir. 1980), upheld jurisdiction to hear a cause of action in tort for injuries caused by torture despite the occurrence of the events in Paraguay, where the defendant ventured into United States territory. Jurisdiction was based on an obscure statute allowing such actions when they involve violations of the law of nations. The case has been criticized, but the possibility of similar jurisdiction on a protected interests theory as well cannot be dismissed. See, Note, TORTuRe as a TORT in Violation of INTERnational LAw, 33 Stanford L. Rev. 
Another alternative-but one of questionable wisdom-might be to arrange for the kidnapping of the offender so that the aggrieved State may punish him. Such a course of action would entail physical dangers and its legality would be questionable, but the United States would be forced to accept the validity of the trial, if not the kidnapping, because the United States accepts the principle mala captus bene detentus. ${ }^{60}$

Realistically, however, it is unlikely that the United States would fail either to prosecute or extradite because in entering into conventions creating such obligations it already had in effect legislation enabling it to fulfill those obligations, and the executive is unlikely to withhold performance of them in the absence of some basis in international law for finding an exception to the general duty. The more likely problems would be differences of opinion as to the applicability of such exceptions and disputes regarding priority of claims where both extradition and prosecution are possible. In the former situation, were it possible to establish the incorrectness of the United States position, performance of the obligation could be expected through cooperation by the executive. In the latter, however, it is likely that the United States would insist on having the option of prosecuting under its own laws first unless an expressly contrary provision were inserted in the relevant international agreement. ${ }^{61}$ Extradition after such prosecution might be possible from the United States point of view, ${ }^{62}$ but because international agreements have provided those obligations in disjunctive form, it would appear unnecessary to face this issue.

In sum, under the United States view of international and municipal law, the only clear basis for a duty to extradite is a treaty. There may, however, be a duty founded in comity to enter into extradition arrangements.

Likewise, the United States would not recognize a duty to prosecute except where such a duty arises from an international agreement to which it is a signatory or one so widely adhered to that it represents an emergent norm of customary international law, and it

880 (1980). Of historical interest, the United States in 1792 negotiations for an extradition agreement with Spain considered a provision calling for civil actions against forg. ers in the country of damage. Moore, note 17 supra at 87-88.

60. The United States does not appear to openly proclaim this, but it is implicit in its practice. Moore, note 17 supra, at 104-05 describes an unusual rendition from Egypt in 1866 and at 114 discusses Ker v. Illinois, 119 U.S. 436 (1886), in which an offender's attempt to defeat a prosecution after he was returned to the United States for trial for an offense not included in the treaty of extradition between the United States and his asylum State was unsuccessful.

61. This is common among states of the union. See note 27 supra.

62. Despite the international law principle ne bis in idem, the United States sees no violation of its own constitutional protection against double jeopardy where two punishments are imposed by different sovereigns. See Bartkus v. Illinois, 359 U.S. 121 (1959) and Franck, AN INTERNATIONAL LAWYER LoOKS at THE BaRTKUS RULE, 34 N.Y.U.L. FEv. 1096 (1959). 
is unlikely that any agreements of the latter type would currently be recognized.

Where duties to prosecute or extradite exist, they may be co-existent if the agreements creating them were to so provide, but such agreements have so far stated them as alternatives.

Where such duties exist and the United States does not fulfill them, the United States would regard itself as internationally responsible, but there is no effective remedy for an aggrieved State to compel extradition or prosecution and in certain circumstances the United States may be unable to extradite or prosecute.

Nevertheless, the United States often attaches other legal consequences to violations of laws of other States and these consequences may partially satisfy the purposes of criminal law cooperation that are the aims of international agreements creating duties of extradition or prosecution. 